\title{
Correction to: A project-based purchasing portfolio matrix applied to the Australian construction industry
}

\section{Louise Bildsten ${ }^{1}$}

Published online: 25 October 2021

(c) Springer Nature Switzerland AG 2021

\section{Correction to: SN Bus Econ (2021) 1:135 \\ https://doi.org/10.1007/s43546-021-00139-5}

After the publication of this article, the author informed us about an error in the figure legend of Fig. 2. The figure legends should read:

Purchasing complexity (need of information, project specificity of products and services).

The original article has been corrected.

The original article can be found online at https://doi.org/10.1007/s43546-021-00139-5.

\section{Louise Bildsten}

louise.bildsten@tlog.lth.se

1 Department of Industrial Management and Logistics, Lund University, Lund, Sweden 